\begin{tabular}{|c|c|}
\hline $\mathbf{M} \mathbf{B} \mathbb{R}$ & Management and Business Review \\
\hline $\begin{array}{c}\text { MANAGEMENT \& } \\
\text { BUSINESS REVIEW } \\
\end{array}$ & $\begin{array}{l}\text { Available at http://ejournal.unikama.ac.id/index.php/mbr } \\
\text { ISSN: } 2541-5808 \text { (online) }\end{array}$ \\
\hline
\end{tabular}

\title{
Analisis pengaruh faktor budaya, faktor sosial, faktor pribadi, dan faktor psikologis terhadap keputusan pembelian polis asuransi
}

\author{
Andri Yuliansyah Putra Utama \\ Program Studi Manajemen, Fakultas Ekonomika dan Bisnis, Universitas Kanjuruhan Malang, \\ Indonesia \\ e-mail: andriyuli@unikama.ac.id
}

$\begin{array}{ll}\text { Article Info: } \\ \text { Receive } & \text { : Maret } 2018 \\ \text { Revised } & : \text { April } 2018 \\ \text { Accepted } & : \text { Mei } 2018 \\ \text { Published } & : \text { Juni } 2018 \\ \text { DOI } & : \text { 10.21067/mbr.v2i1.4724 } \\ \text { Copyright } & : \text { Management and } \\ & \text { Business Review }\end{array}$

Keywords:

Faktor budaya, sosial, pribadi, psikologis, dan keputusan pembelian

\begin{abstract}
This study aims to determine the causal relationship between cultural, social, personal and psychological factors with purchasing decisions. This research uses a quantitative approach design, the type of research is explanatory research. The population is the insurance customer of PT. AXA Financial Indonesia, a Malang branch office with 238 customers. The sample used is insurance customers who have purchased insurance products at PT. AXA Financial Indonesia Malang branch, with a total of 150 people, was taken by the random sampling method. The data collection technique used a questionnaire which was arranged with a 5-point Likert scale. The data analysis technique used Multiple Linear Regression analysis. The results of the analysis show that cultural, social, personal, and psychological factors have a positive and significant effect on purchasing decisions. Social factors are variables that have a dominant influence on purchasing decisions.
\end{abstract}

\begin{abstract}
Abstrak: Penelitian bertujuan untuk mengetahui hubungan kausal antara faktor budaya, sosial, pribadi, dan psikologis dengan keputusan pembelian. Penelitian menggunakan desain pendekatan kuantitatif, jenis penelitian explanatory research yang. Populasi adalah nasabah asuransi PT. AXA Financial Indonesia, kantor cabang Malang yang berjumlah 238 nasabah. Sampel yang digunakan adalah nasabah asuransi yang pernah membeli produk-produk asuransi di PT. AXA Financial Indonesia cabang Malang, dengan jumlah 150 orang, diambil dengan metode Random Sampling. Teknik pengumpulan data menggunakan Kuesioner yang disusun dengan Skala Likert 5 poin. Teknik analisis data menggunakan analisis Regresi Linier Berganda. Hasil analisis menunjukkan bahwa faktor budaya, sosial, pribadi, dan psikologis berpengaruh positif dan signifikan terhadap keputusan pembelian. Faktor sosial merupakan variabel yang berpengaruh dominan terhadap keputusan pembelian.
\end{abstract}




\section{Pendahuluan}

Asuransi sebagai bisnis yang bergerak di bidang jasa harus berorientasi pada kepuasan nasabah karena nasabah merupakan salah satu basis bagi perkembangan bisnis asuransi itu sendiri (Margaretha, 2004). Kita tahu bahwa di negara maju seperti Jepang, China, Belanda, dan Amerika kesadaran akan berasuransi semakin tinggi, sedangkan Indonesia sebagai negara berkembang seharusnya mempunyai gambaran atau mempunyai pola berfikir seperti halnya yang dilakukan oleh negaranegara maju mengenai kesadaran dalam berasuransi. Belum adanya kesadaran masyarakat Indonesia mengenai asuransi, hal inilah yang menarik minat perusahaan-perusahaan asuransi asing untuk mengembangkan pangsa pasarnya masuk ke Indonesia, dengan tujuan untuk mendapatkan suatu profit/keuntungan yang lebih, sehingga menjadikan tingkat keuangan atau dalam asuransi disebut RBC (Risk Based Capital) dari perusahaan tersebut semakin kokoh. Tentunya perusahaan asing tersebut harus bersaing dengan perusahaan asuransi lokal yang ada di Indonesia. Ada berbagai macam bentuk jaminan yang ditawarkan serta inovasi produk-produk asuransi dan juga besarnya premi yang di tawarkan kepada calon nasabah tersebut, untuk dapat bersaing dan mendapatkan seorang nasabah atau konsumen.

Menggiurkannya keuntungan (revenue) dari berbisnis asuransi dan semakin terbukanya peluang pasar membuat persaingan semakin sengit. Sedikitnya ada lima perusahaan asuransi yang menjadi pemimpin dalam pasar asuransi di Indonesia, yaitu AXA Financial Indonesia, Prudential Life Assurance, AIA Financial, Manulife Indonesia, dan Allianz Life. Situasi persaingan tersebut makin diperhangat oleh frontfront persaingan antar para perusahaan asuransi. Sedikitnya terdapat enam aspek front persaingan antara perusahaan asuransi tersebut, antara lain: aspek kekuatan keuangan (asset) perusahaan, aspek pelayanan, aspek kelancaran klaim, aspek varian produk, harga premi, dan manfaat produk. Menghadapi persaingan bisnis tersebut maka perusahaan asuransi harus senantiasa proaktif dan inovatif dalam merancang sebuah strategi-strategi pemasaran serta meningkatkan kualitas pelayanannya.

Menurut hasil survei AAJI (Asosiasi Asuransi Jiwa Indonesia) dari total 24 juta jiwa penduduk Indonesia, masih sekitar $42,34 \%$ penduduk Indonesia yang belum mempunyai jaminan asuransi. Itupun yang mempunyai asuransi pribadi hanya $18 \%$, sedangkan $32,37 \%$ mendapatkan jamkesmas dari pemerintah, serta $7,29 \%$ askes PNS, TNI, POLRI. Ini menandakan bahwa masyarakat Indonesia belum menyadari pentingnya asuransi serta minat beli masyarakat masih rendah.

Pemilihan nasabah asuransi sebagai objek penelitian karena mengingat banyaknya manfaat yang didapatkan dari berasuransi tetapi masyarakat belum menyadari akan pentingnya asuransi, serta minat beli masyarakat terhadap asuransi masih kurang, dapat dilihat dari perolehan jumlah nasabah PT. AXA Financial Indonesia cabang Malang saat ini. Pemilihan PT. AXA Financial Indonesia sebagai 
objek atau tempat penelitian karena AXA mendapatkan banyak sekali penghargaan yaitu, telah diakui Interbrand sebagai merek asuransi nomor satu dunia selama sembilan tahun berturut-turut sejak tahun 2009-2017, nomor satu Global Insurance Brand Fortune Global sejak 2013-2017, nomor satu Word Most Innovativ Insurance Company (BCG), nomor satu Best Life Insurance Corporate Image sejak tahun 2015-2017, dengan banyaknya penghargaan yang didapatkan serta jumlah nasabah yang diperoleh saat ini, berarti penjualan produk AXA dikota Malang masih rendah, oleh karena itu dilakukan penelitian dari segi perilaku konsumen. Adapun tujuan penelitian adalah untuk mengetahui pengaruh faktor budaya, faktor sosial, faktor pribadi, dan faktor psikologis terhadap keputusan pembelian polis asuransi di PT. AXA Financial Indonesia cabang Malang.

\section{Hubungan faktor budaya dengan keputusan pembelian}

Menurut Kotler \& Amstrong (2012), faktor budaya adalah kumpulan nilai dasar, persepsi, keinginan, dan perilaku yang dipelajari oleh anggota masyarakat dari keluarga dan institusi penting lainnya. Penelitian yang dilakukan oleh Ghoni \& Bodroastuti (2010) pengaruh faktor budaya, sosial, pribadi, psikologi terhadap keputusan perilaku konsumen, membuktikan bahwa faktor budaya berpengaruh signifikan terhadap keputusan pembelian. Dapat disimpulkan bahwa faktor budaya mempengaruhi keputusan pembelian. Selanjutnya penelitian Susanto (2016) dan Putri et al. (2016) menjelaskan bahwa faktor budaya mempengaruhi keputusan pembelian konsumen.

$\mathrm{H}_{1}$ : Faktor budaya berpengaruh signifikan terhadap keputusan pembelian polis asuransi Axa.

\section{Hubungan faktor sosial dengan keputusan pembelian}

Menurut Kotler \& Amstrong (2012), faktor sosial merupakan pengaruh dari sekelompok orang yang mempengaruhi seorang individu untuk mengikuti kebiasaannya. Penelitian yang dilakukan oleh Puspitarini (2013) tentang pengaruh faktor budaya, sosial, pribadi, dan psikologi terhadap proses keputusan pembelian produk Pizza, diperoleh hasil bahwa Faktor sosial berpengaruh positif terhadap proses keputusan pembelian produk Pizza. Demikian pula hasil penelitian Susanto (2016) dan Ghoni \& Bodroastuti (2010) yang menyatakan bahwa faktor sosial mempengaruhi keputusan pembelian.

$\mathrm{H}_{2}$ : Faktor sosial berpengaruh signifikan terhadap keputusan pembelian polis asuransi Axa.

\section{Hubungan faktor pribadi dengan keputusan pembelian}

Menurut Kotler \& Amstrong (2012), keputusan pembelian juga dipengaruhi oleh karakteristik pribadi yang terdiri dari usia dan tahap siklus hidup pembeli, pekerjaan, keadaan ekonomi, gaya hidup, serta kepribadian dan konsep diri. 
Penelitian yang di lakukan Susanto (2016), Ghoni \& Bodroastuti (2010), dan Puspitarini (2013) membuktikan bahwa faktor pribadi berpengaruh signifikan terhadap keputusan pembelian konsumen.

$\mathrm{H}_{3}$ : Faktor pribadi berpengaruh signifikan terhadap keputusan pembelian polis asuransi Axa.

\section{Hubungan faktor psikologis dengan keputusan pembelian}

Menurut Kotler \& Amstrong (2012), pilihan pembelian seseorang dipengaruhi oleh empat faktor yaitu motivasi, persepsi, pengetahuan dan keyakinan dan sikap. Pendapat lain tentang faktor psikologis adalah menjelaskan dengan pemahaman tentang apa yang terjadi dalam pikiran seseorang daripada semata-mata memahami bagaimana otak seseorang berfungsi (Widiyono \& Pakkana, 2013). Penelitian yang dilakukan (Kartikasari, 2013) tentang pengaruh perilaku konsumen terhadap keputusan pembelian, menunjukkan bahwa variabel psikologis memiliki pengaruh secara parsial dan signifikan terhadap struktur keputusan pembelian. Demikian pula Susanto (2016), Ghoni \& Bodroastuti (2010), dan Puspitarini (2013) membuktikan bahwa faktor psikologis berpengaruh signifikan terhadap keputusan pembelian konsumen

$\mathrm{H}_{4}$ : Faktor psikologis berpengaruh signifikan terhadap keputusan pembelian polis asuransi Axa.

\section{Metode}

Menggunakan jenis penelitian explanatory research atau penelitian penjelasan dengan menggunakan metode survei, dalam metode survei, informasi data dikumpulkan dari responden dengan menggunakan koesioner. Penelitian ini mengambil sampel nasabah asuransi yang pernah membeli produk-produk asuransi di PT. AXA Financial Indonesia cabang Malang, sebanyak 238 nasabah yang diambil dengan teknik random sampling. Variabel penelitian terdiri dari variabel bebas faktor budaya, faktor sossial, faktor pribadi, dan faktor psikologis, sedangkan variabel terikat adalah keputusan pembelian. Indikator masing-masing variabel disajikan pada tabel 1.

Tabel 1. Variabel dan Indikator

\begin{tabular}{ccl}
\hline No & \multicolumn{1}{c}{ Variabel } & \multicolumn{1}{c}{ Indikator } \\
\hline 1 & Faktor Budaya & $\mathbf{X}_{1.1}$ Wilayah geografis \\
& $\left(\mathrm{X}_{1}\right)$ & $\mathbf{X}_{1.2}$ Kelas sosial \\
& $\mathbf{X}_{1.3}$ Pergeseran budaya \\
& $\mathbf{X}_{1.4}$ Tingkah laku \\
\hline 2 & $\mathbf{X}_{2.1}$ Kelompok referensi \\
& Faktor Sosial & $\mathbf{X}_{2.2}$ Keluarga \\
& $\left(\mathrm{X}_{2}\right)$ & $\mathbf{X}_{2.3}$ Status dan peran \\
& $\mathbf{X}_{2.4}$ Pendidikan \\
\hline
\end{tabular}


Management and Business Review, 2(1) 2018, 50-61

\begin{tabular}{cll}
\hline No & \multicolumn{1}{c}{ Variabel } & \multicolumn{1}{c}{ Indikator } \\
\hline 3 & Faktor Pribadi & $\mathbf{X}_{3.1}$ Usia \\
& $\left(\mathrm{X}_{3}\right)$ & $\mathbf{X}_{3.2}$ Pekerjaan \\
& $\mathbf{X}_{3.3}$ Keadaan ekonomi \\
& $\mathbf{X}_{3.4}$ Gaya hidup \\
\hline 4 & Faktor Psikologis $\left(\mathrm{X}_{4}\right)$ & $\mathbf{X}_{4.1}$ Motivasi \\
& $\mathbf{X}_{4.2}$ Persepsi \\
& $\mathbf{X}_{4.3}$ Keyakinan \\
& $\mathbf{X}_{4.4}$ Pengetahuan \\
\hline & & $\mathbf{Y}_{\mathbf{1}}$ Pengenalan masalah \\
& & $\mathbf{Y}_{2}$ Pencarian informasi \\
& Keputusan Pembelian $(\mathrm{Y})$ & $\mathbf{Y}_{3}$ Evaluasi alternatif \\
& & $\mathbf{Y}_{4}$ Pembelian \\
& & $\mathbf{Y}_{5}$ Perilaku pasca pembelian \\
\hline
\end{tabular}

Instrumen penelitian menggunakan kuesioner yang dibuat dengan menggunakan skala Likert 5 tingkat, yang sebelumnya telah dilakukan uji validitas dan reliabilitas. Sedangkan teknik analisis data menggunakan Regresi Linear Berganda, dengan dilengkapi pengujian asumsi klasik. Teknik analisis Regresi Linier digunakan untuk menguji hubungan kausal antara variabel bebas terhadap variabel terikat (Sarwoko, 2018).

\section{Hasil}

\section{Analisis Regresi Linier Berganda}

Model regresi linier berganda telah dilakukan uji asumsi klasik, hasilnya terpenuhi asumsi normalitas, tidak terjadi multikolinieritas dan heteroskedastisitas, dengan demikian model regresi dapat digunakan secara akurat untuk menganalisis pengaruh variabel bebas terhadap variabel terikat. Analisis Regresi digunakan untuk mengetahui seberapa besar pengaruh variabel bebas yaitu: faktor budaya, faktor sosial, faktor pribadi, dan faktor psikologis terhadap variabel terikatnya yaitu keputusan pembelian, untuk menguji analisis regresi linier berganda dilakukan dengan menggunakan SPSS. Hasil analisis regresi liner berganda disajikan pada tabel 2.

Nilai koefisien regresi pada variabel faktor budaya $\left(\mathrm{X}_{1}\right)$ memiliki nilai $\mathrm{B}$ (Unstandardized Coefficients) sebesar 0,192. Hal ini menyatakan bahwa setiap satuan variabel faktor budaya akan memberi pengaruh sebesar 0,192 terhadap keputusan pembelian, apabila variabel lainnya tetap. Data tersebut menunjukan bahwa faktor budaya berpengaruh positif (searah) terhadap keputusan pembelian polis asuransi.

Nilai koefisien regresi pada variabel faktor sosial $\left(X_{2}\right)$ memiliki nilai $B$ (Unstandardized Coefficients) sebesar 0,212. Hal ini menyatakan bahwa setiap satuan 
variabel faktor budaya akan memberi pengaruh sebesar 0,212 terhadap keputusan pembelian, apabila variabel lainnya tetap. Data tersebut menunjukan bahwa faktor sosial berpengaruh positif (searah) terhadap keputusan pembelian polis asuransi.

Tabel 2. Hasil Analisis Regresi Linier Berganda

\begin{tabular}{lcccc}
\hline \multicolumn{1}{c}{ Variabel bebas } & $\mathrm{b}$ & Beta & $\mathrm{T}$ & Sig. t \\
\hline Faktor Budaya & 0,192 & 0,261 & 3,793 & 0,000 \\
Faktor Sosial & 0,212 & 0,281 & 4,460 & 0,000 \\
Faktor Pribadi & 0,188 & 0,248 & 3,600 & 0,000 \\
Faktor Psikologis & 0,110 & 0,182 & 2,326 & 0,021 \\
\hline F-Hitung & 61,008 & & \\
Sign-F & 0,000 & & \\
R Square (R ${ }^{2}$ O,627 & & & \\
Variabel terikat: Keputusan Pembelian & &
\end{tabular}

Nilai koefisien regresi pada variabel faktor pribadi $\left(X_{3}\right)$ memiliki nilai B (Unstandardized Coefficients) sebesar 0,188. Hal ini menyatakan bahwa setiap satuan variabel faktor budaya akan memberi pengaruh sebesar 0,188 terhadap keputusan pembelian, apabila variabel lainnya tetap. Data tersebut menunjukan bahwa faktor pribadi berpengaruh positif (searah) terhadap keputusan pembelian polis asuransi.

Nilai koefisien regresi pada variabel faktor psikologis $\left(\mathrm{X}_{4}\right)$ memiliki nilai B (Unstandardized Coefficients) sebesar 0,110. Hal ini menyatakan bahwa setiap satuan variabel faktor budaya akan memberi pengaruh sebesar 0,110 terhadap keputusan pembelian, apabila variabel lainnya tetap. Data tersebut menunjukan bahwa faktor psikologis berpengaruh positif (searah) terhadap keputusan pembelian polis asuransi.

Berdasarkan hasil analisis determinasi diperoleh $\mathrm{R}$ Square $\left(\mathrm{R}^{2}\right)$ sebesar 0,627 atau $62,7 \%$. Hal ini menunjukkan bahwa presentase sumbangan pengaruh variabel independen (faktor budaya, faktor sosial, faktor pribadi, dan faktor psikologis) terhadap variabel dependen (keputusan pembelian) sebesar 62,7\% sedangkan sisanya yaitu 37,3\% dipengaruhi oleh variabel lain yang tidak diteliti dalam penelitian ini.

Hasil analisis menunjukkan bahwa $\mathrm{F}$ hitung 61,008 > F tabel 2,43 dengan tingkat signifikansi sebesar 0,000 < 0,05. Jadi dapat disimpulkan ada pengaruh simultan atau bersama-sama antara ke empat variabel independen (faktor budaya, faktor sosial, faktor pribadi, dan faktor psikologis) terhadap variabel dependen (keputusan pembelian) dan model yang digunakan dalam penelitian ini adalah baik.

\section{Uji Hipotesis}

Variabel faktor budaya $\left(X_{1}\right)$ menunjukkan signifikan $T$ sebesar $0,000<0,05$ berarti terdapat pengaruh yang signifikan dari faktor budaya terhadap variabel 
keputusan pembelian (Y), dengan demikian dapat disimpulkan bahwa $\mathrm{H} 1$ diterima. Variabel faktor sosial $\left(\mathrm{X}_{2}\right)$ menunjukkan signifikan $\mathrm{T}$ sebesar 0,000 0,05 berarti terdapat pengaruh yang signifikan dari faktor sosial terhadap variabel keputusan pembelian (Y), dengan demikian dapat disimpulkan bahwa $\mathrm{H} 2$ diterima. Variabel faktor pribadi $\left(\mathrm{X}_{3}\right)$ menunjukkan signifikan $\mathrm{T}$ sebesar $0,000<0,05$ berarti terdapat pengaruh yang signifikan dari faktor budaya terhadap variabel keputusan pembelian (Y), dengan demikian dapat disimpulkan bahwa $\mathrm{H} 3$ diterima. Variabel faktor psikologis $\left(X_{4}\right)$ menunjukkan signifikan T sebesar $0,021<0,05$ berarti terdapat pengaruh yang signifikan dari faktor budaya terhadap variabel keputusan pembelian (Y), dengan demikian dapat disimpulkan bahwa H4 diterima. Dari penjabaran diatas menunjukkan bahwa semua variabel independen (faktor budaya, faktor sosial, faktor pribadi dan faktor psikologis) mempunyai pengaruh yang signifikan terhadap variabel dependen (keputusan pembelian), karena memiliki nilai signifikan $\mathrm{T}<0,05$.

\section{Pembahasan}

\section{Pengaruh faktor budaya terhadap keputusan pembelian}

Berdasarkan hasil analisis regresi linier berganda dapat diketahui bahwa faktor budaya memiliki pengaruh positif dan signifikan terhadap keputusan pembelian. Hal ini berarti jika semakin baik memperhatikan faktor budaya calon nasabah maka akan meningkatkan terjadinya keputusan pembelian polis asuransi AXA. Hasil penelitian ini memiliki sejalan dan mendukung penelitian yang dilakukan oleh Ghoni \& Bodroastuti (2010), Susanto (2016) dan Putri et al. (2016) yang menyatakan bahwa faktor budaya mempengaruhi keputusan pembelian konsumen. Menurut (Kotler \& Amstrong, 2012), faktor budaya adalah kumpulan nilai dasar, persepsi, keinginan, dan perilaku yang dipelajari oleh anggota masyarakat dari keluarga dan institusi penting lainnya.

Hasil analisis deskriptif menjelaskan bahwa untuk variabel faktor budaya, terlihat bahwa jawaban responden yang memiliki rata-rata tertingi adalah tentang status ekonomi menjadi pemicu pembelian polis asuransi. Sedangkan jawaban responden yang memiliki nilai rata-rata terendah adalah tentang kemajuan budaya yang sangat pesat menjadi keharusan memiliki polis asuransi, perlu mendapat perhatian yaitu masih ada sebagian orang yang menganggap di era kemajuan budaya modern seperti sekarang ini tidak menjadi keharusan memiliki asuransi, ini dilihat dari 92 orang yang tidak sepakat atau bertolak belakang dengan kemajuan budaya. Dapat disimpulkan nasabah cinderung membeli polis asuransi karena status ekonomi mereka walaupun budaya mengalami kemajuan yang sangat pesat, jadi PT. AXA Financial Indonesia cabang Malang harus menanamkan dibenak calon nasabah bahwa di era kemajuan budaya modern yang sangat pesat seperti sekarang ini pola budaya mengelolah keuangan keluarga harus dirubah, oleh karena itu harus 
memiliki polis asuransi untuk mengelola keuangan mereka dengan baik dan aman sesuai tujuan yang diinginkan.

\section{Pengaruh Faktor Sosial Terhadap Keputusan Pembelian}

Berdasarkan hasil analisis regresi linier berganda dapat diketahui bahwa faktor sosial memiliki pengaruh positif dan signifikan terhadap keputusan pembelian. Hal ini berarti jika semakin baik memperhatikan faktor sosial calon nasabah maka akan meningkatkan terjadinya keputusan pembelian polis asuransi AXA. Nilai koefisien regresi linier berganda pada variabel faktor sosial mempunyai nilai Beta (Standardized Coefficients) positif (searah) dan signifikan. Dapat disimpulkan secara parsial variabel faktor sosial berpengaruh positif dan signifikan terhadap variabel keputusan pembelian polis asuransi PT. AXA Financial Indonesia cabang Malang.

Hasil penelitian ini mendukung penelitian Puspitarini (2013) yang membuktikan hasil penelitian dan analisis data menunjukkan bahwa Faktor sosial berpengaruh positif terhadap proses keputusan pembelian produk Pizza, serta sejalan dengan penelitian Susanto (2016) dan Ghoni \& Bodroastuti (2010) yang menyatakan bahwa faktor sosial mempengaruhi keputusan pembelian. Menurut Kotler dan Armstrong (2014), faktor sosial merupakan pengaruh dari sekelompok orang yang mempengaruhi seorang individu untuk mengikuti kebiasaannya.

Hasil analisis deskriptif variabel faktor sosial, terlihat bahwa jawaban responden yang memiliki rata-rata tertingi adalah tentang jenjang pendidikan mempengaruhi pola fikir terhadap pembelian polis asuransi. Sedangkan jawaban yang memiliki nilai rata-rata terendah adalah membeli produk asuransi karena rekomendasi teman, membeli asuransi karena ada anggota keluarga yang merasakan manfaat, da membeli asuransi karena sudah aturan dari tempat kerja, sehingga perlu mendapat perhatian, pertama yaitu 81 orang tidak sepakat tentang adanya rekomendasi teman dalam pembelian asuransi, kedua yaitu 79 orang tidak sepakat dengan adanya anggota keluarga yang pernah merasakan manfaat memicu pembelian asuransi, dan yang ketiga yaitu 79 orang tidak sepakat dengan pernyataan membeli asuransi karena sudah aturan dari tempat kerja. Dapat disimpulkan nasabah lebih cinderung membeli asuransi karena jenjang pendidikan mereka mempengaruhi pola fikir dirinya terhadap asuransi dari pada rekomendasi dari teman, keluarga ataupun tempat kerja. Jadi PT. AXA Financial Indonesia cabang Malang harus melakukan strategi pemasaran menggunakan asking referral meminta referensi dari nasabah yang sudah pernah membeli karena itu merupakan sarana membangun link dan memperluas pasar dan persentase closing jauh lebih besar dengan menggunakan referrals, serta lebih gencar melakukan kerjasamakerjasama dengan institusi, lembaga maupun perusahaan, karena jika orang yang berpengaruh dalam sebuah institusi, lembaga dan perusahaan dapat diajak kerjasama asuransi maka secara otomatis orang-orang yang ada didalam institusi, 
lembaga atau perusahaan tersebut sudah pasti ikut asuransi jika sudah aturan/kebijakan, walaupun pada item-item tersebut ada yang tidak sepakat atau bertolak belakang terhadap keputusan pembelian polis asuransi.

\section{Pengaruh Faktor Pribadi Terhadap Keputusan Pembelian}

Berdasarkan hasil analisis regresi linier berganda dapat diketahui bahwa faktor pribadi memiliki pengaruh positif dan signifikan terhadap keputusan pembelian. Hal ini berarti jika semakin baik memperhatikan faktor pribadi calon nasabah maka akan meningkatkan terjadinya keputusan pembelian polis asuransi AXA. Nilai koefisien regresi linier berganda pada variabel faktor pribadi mempunyai nilai Beta (Standardized Coefficients) positif dan nilai signifikansinya 0,000. Dapat disimpulkan secara parsial variabel faktor pribadi $\left(X_{4}\right)$ berpengaruh positif dan signifikan terhadap variabel keputusan pembelian polis asuransi PT. AXA Financial Indonesia cabang Malang.

Hasil penelitian ini sejalan dengan penelitian Susanto (2016) yang membuktikan bahwa faktor pribadi berpengaruh signifikan terhadap keputusan pembelian konsumen semen Tonasa. Selain itu mendukung penelitian dari Ghoni \& Bodroastuti (2010), dan Puspitarini (2013) membuktikan bahwa faktor pribadi berpengaruh signifikan terhadap keputusan pembelian konsumen. Menurut Kotler dan Armstrong (2014), keputusan pembelian juga dipengaruhi oleh karakteristik pribadi yang terdiri dari usia dan tahap siklus hidup pembeli, pekerjaan, keadaan ekonomi, gaya hidup, serta kepribadian dan konsep diri.

Hasil analisis deskriptif variabel faktor pribadi, terlihat bahwa jawaban yang memiliki rata-rata tertinggi adalah terkait usia sangat menentukan seseorang untuk membeli polis asuransi dan pendapatan saya mencukupi untuk pembelian asuransi. Sedangkan jawaban yang memiliki nilai rata-rata terendah ada 2 item, yaitu menggunakan jasa asuransi dapat mencerminkan gaya hidup dan membeli polis asuransi untuk merubah gaya hidup agar terlihat berkesan. Perlu mendapat perhatian, pertama yaitu 92 orang tidak sepakat tentang menggunakan jasa asuransi, dapat mencerminkan gaya hidup, kedua yaitu 104 orang tidak sepakat dengan membeli polis asuransi untuk merubah gaya hidup agar terlihat berkesan. Dapat disimpulkan nasabah lebih cinderung membeli asuransi yang pertama karena faktor usia, dapat dilihat dari total 150 responden usia lebih dari 40 tahun tercatat paling banyak, dan yang kedua adalah faktor pendapatan mereka, jika semakin besar pendapatan artinya presentase pembelian polis asuransi juga semakin tinggi. Jadi PT. AXA Financial Indonesia cabang Malang dalam pemasarannya harus mengutamakan usia 40 tahun keatas karena usia 40 keatas lebih membutuhkan asuransi misalnya asuransi kesehatan ataupun asuransi dana pensiun apalagi dalam usia 40 tahun dari segi pendapatan pastinya sudah mapan. 


\section{Pengaruh Faktor Psikologis Terhadap Keputusan Pembelian}

Berdasarkan hasil analisis regresi linier berganda dapat diketahui bahwa faktor psikologis memiliki pengaruh positif dan signifikan terhadap keputusan pembelian. Hal ini berarti jika semakin baik memperhatikan faktor psikologis calon nasabah maka akan meningkatkan terjadinya keputusan pembelian polis asuransi AXA. Nilai koefisien regresi linier berganda pada variabel faktor psikologis mempunyai nilai Beta (Standardized Coefficients) bertanda positif (searah) dengan nilai signifikansinya 0,021 dapat disimpulkan secara parsial variabel faktor psikologis $\left(X_{4}\right)$ berpengaruh positif dan signifikan terhadap variabel keputusan pembelian polis asuransi PT. AXA Financial Indonesia cabang Malang.

Hasil penelitian ini sejalan dengan penelitian Kartikasari (2013) yang membuktikan bahwa variabel psikologis memiliki pengaruh secara parsial dan signifikan terhadap struktur keputusan pembelian. Selain itu mendukung penelitian Susanto (2016), Ghoni \& Bodroastuti (2010), dan Puspitarini (2013) membuktikan bahwa faktor psikologis berpengaruh signifikan terhadap keputusan pembelian konsumen. Menurut Kotler dan Armstrong (2014), pilihan pembelian seseorang dipengaruhi oleh empat faktor yaitu motivasi, persepsi, pengetahuan dan keyakinan dan sikap. Pendapat lain tentang faktor psikologis adalah menjelaskan dengan pemahaman tentang apa yang terjadi dalam pikiran seseorang daripada sematamata memahami bagaimana otak seseorang berfungsi Widiyono dan Pakkanna (2013).

Hasil analisis deskriptif variabel faktor psikologis, terlihat bahwa pernyataan yang memiliki rata-rata tertingi yaitu membeli polis asuransi AXA karena produknya beragam. Sedangkan yang memiliki nilai rata-rata terendah, yaitu membeli polis asuransi karena termotivasi seseorang. Perlu mendapat perhatian, yaitu 67 orang tidak sepakat bahwa membeli asuransi karena motivasi seseorang. Dapat disimpulkan nasabah lebih cinderung membeli asuransi karena produk AXA yang beragam dari pada motivasi dari seseorang. Jadi PT. AXA Financial Indonesia cabang Malang dalam pemasarannya harus lebih mengenalkan dan memberikan pengetahuan akan produk-produk asuransi AXA dan apa saja manfaatnya, semakin calon nasabah mengetahui keberagaman produk yang dimiliki AXA semakin nasabah bisa mencari asuransi apa yang mereka butuhkan.

\section{Simpulan}

Hasil penelitian telah membuktikan bahwa faktor budaya berpengaruh positif dan signifikan terhadap proses keputusan pembelian polis asuransi PT. AXA Financial Indonesia, kantor cabang Malang. Dapat disimpulkan secara parsial variabel faktor budaya $\left(\mathrm{X}_{1}\right)$ berpengaruh positif dan signifikan terhadap variabel keputusan pembelian polis asuransi PT. AXA Financial Indonesia cabang Malang. Faktor sosial berpengaruh positif dan signifikan terhadap proses keputusan 
pembelian polis asuransi PT. AXA Financial Indonesia, kantor cabang Malang. Dapat disimpulkan secara parsial variabel faktor sosial $\left(\mathrm{X}_{2}\right)$ berpengaruh positif dan signifikan terhadap variabel keputusan pembelian polis asuransi PT. AXA Financial Indonesia cabang Malang. Faktor pribadi berpengaruh positif dan signifikan terhadap proses keputusan pembelian polis asuransi PT. AXA Financial Indonesia, kantor cabang Malang. Dapat disimpulkan secara parsial variabel faktor pribadi $\left(X_{3}\right)$ berpengaruh positif dan signifikan terhadap variabel keputusan pembelian polis asuransi PT. AXA Financial Indonesia cabang Malang. Faktor psikologis berpengaruh positif dan signifikan terhadap proses keputusan pembelian polis asuransi PT. AXA Financial Indonesia, kantor cabang Malang. Dapat disimpulkan secara parsial variabel faktor psikologis $\left(\mathrm{X}_{4}\right)$ berpengaruh positif dan signifikan terhadap variabel keputusan pembelian polis asuransi PT. AXA Financial Indonesia cabang Malang.

\section{Daftar Pustaka}

Ghoni, A., \& Bodroastuti, T. (2010). Pengaruh Faktor Budaya, Sosial, Pribadi Dan Psikologi Terhadap Perilaku Konsumen (Studi Pada Pembelian Rumah Di Perumahan Griya Utama Banjardowo Semarang). Jurnal Kajian Akuntansi Dan Bisnis, 1(1), 103179.

Kartikasari, D. (2013). Pengaruh perilaku konsumen terhadap keputusan pembelian (Penelitian pada mahasiswa Administrasi Bisnis angkatan 2012/2013 Fakultas Ilmu Administrasi Universitas Brawijaya yang mengkonsumsi produk mie instan merek Indomie). Jurnal Administrasi Bisnis, 3(2).

Kotler, P., \& Amstrong, G. (2012). Prinsip-Prinsip Pemasaran. Edisi 13. Jilid 1. Erlangga.

Margaretha, M. (2004). Studi Mengenai Loyalitas Pelanggan pada Divisi Asuransi kumpulan AJB Bumi Putera 1912 (studi Kasus di Jawa Tengah). Jurnal Sains Pemasaran Indonesia, 3(3), 289-308.

Puspitarini, D. (2013). Pengaruh Faktor Kebudayaan, Sosial, Pribadi, Dan Psikologi Terhadap Proses Keputusan Pembelian Produk Pizza (Studi Pada Pizza Hut Yogyakarta). Program Studi Manajemen Jurusan Manajemen FE-UNY. Skripsi.

Putri, A., Lindawati, L., \& Rosha, Z. (2016). Pengaruh faktor budaya terhadap keputusanpembelian sovenir dan bordiran di Toko Silungkang Nelvi Ratulangi Padang. Jurnal Fakultas Ekonomi, 9(2).

Sarwoko, E. (2018). Analisis Statistik Menggunakan SPSS 22. Media Nusa Creative.

Susanto, A. B. (2016). the Influence of Cultural, Social, Personal, and Psychological 
on Consumer Purchase Decision-Study on Tonasa Cement Product in Manado City. EFISIENSI, 16(1).

Widiyono \& Pakkana, M. (2013). Pengantar Bisnis (Respon Terhadap Dinamika Global). Jakarta: Mitra Wacana Media. 